UNITED STATES DEPARTMENT OF THE INTERIOR GEOLOGICAL SURVEY

\title{
Analytical results and sample location map \\ of heavy-mineral concentrates from the \\ Sierra Ladrones Wilderness Study Area, \\ Socorro County, New Mexico
}

\author{
By \\ Michael S. Allen ${ }^{1}$, Janet L. Jones ${ }^{1}$, \\ Turner, Robert L. ${ }^{1}$, and Day, Gordon ${ }^{2}$
}

Open-File Report 88-249

This report is preliminary and has not been reviewed for conformity with U.S. Geological Survey editorial standards and stratigraphic nomenclature. Any use of trade names is for descriptive purposes oniy and does not imply endorsement by the USGS.

1988

1U.S. Geological Survey, DFC, Box 25046, MS 973, Denver, CO 80225-0046

${ }^{2}$ Retired 


\section{CONTENTS}

Page

Studies Related to Wilderness................................

Introduction.........................................

Method of Study.....................................

Sample Medium..................................... 1

Sample Collection...................................

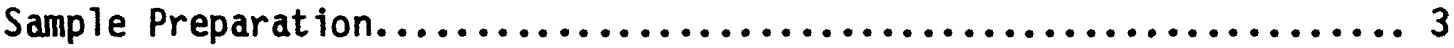

Sample Analysis.....................................

Rock Analysis Storage System.............................. 5

Description of Data Table................................

References Cited....................................

ILLUSTRATIONS

Figure 1. Location map of the Sierra Ladrones Wilderness Study Area, Socorro County, New Mexico............................... 2

Figure 2. Sample location map of the Sierra Ladrones Wilderness Study

Area, Socorro County, New Mexico........................... 4

\section{TABLES}

Table 1. Limits of determination for spectrographic analysis of heavy-mineral concentrates............................. 6

Table 2. Results of analyses of heavy-mineral concentrates.......... 7 


\section{STUDIES RELATED TO WILDERNESS}

\section{Bureau of Land Management Wilderness Study Areas}

The Federal Land Policy and Management Act (Public Law 94-579, October 21, 1976) requires the U.S. Geological Survey and the U.S. Bureau of Mines to conduct mineral surveys on certain Federal lands to determine the ir mineral values, if any. Results must be made available to the public and must be submitted to the President and the Congress. This report presents the results of the geochemical component of a mineral survey of the Sierra Ladrones Wilderness Study Area (NM-020-016), Socorro County, New Mexico.

\section{INTRODUCTION}

In November, 1984, the U.S. Geological Survey conducted a reconna issance geochemical survey of the Sierra Ladrones Wilderness Study Area (WSA), Socorro County, New Mexico. Sampling was carried out by Robert Turner, Rick Graff, and Allen Phillips.

2. The Sierra Ladrones WSA comprises 31,804 acres or about $50 \mathrm{sq} \mathrm{mi}$ (136. $\mathrm{km}^{2}$ ) in the northwest corner of Socorro County, about $50 \mathrm{mi}$ northwest of Socorro (fig. 1). Access to the area is provided by numerous unimproved roads branching from a graded road. This graded road runs north from U.S. Highway 60 along the western and northern margins of the area.

The study area is located along the western margin of the Rio Grande depression and is dominantly comprised of a westward-dipping fault block bounded by Cenozoic high-angle faults. The core of the area is underlain by Precambrian rocks, while along the western margin Paleozoic sedimentary rocks unconformably overlie Precambrian rocks. The Precambrian rocks have been divided into 15 units by Condie (1976), which can be grouped into a metavolcanic sequence, a metasedimentary sequence, and younger granitic intrusive rocks. Paleozoic rocks of the area are dominantly of the Pennsylvanian age Magdalena Group including the Sandia Formation and the carbonate units of the Madera Formation. Known mineralization in the area includes conformable copper-bearing fissure veins in metasediments, believed to be related to intrusion of the granitic bodies, and copper-bearing quartz and barite veins associated with faults along the eastern marg in of the area (Black, 1964). Detailed descriptions of the geology of the area are presented by Noble (1950), Black (1964), Haederle (1966), and Condie (1976).

The Sierra Ladrones WSA is characterized physiographically by the rugged Ladron Mountains. On the east side the Ladron Mountains rise abruptly from gently sloping alluvial fans at an elevation of $5,600 \mathrm{ft}(1700 \mathrm{~m})$ to an elevation of $9,176 \mathrm{ft}(2794 \mathrm{~m})$ on Ladron Peak. On the west side, the thick section of Paleozoic sedimentary rocks lap up onto the Precambrian, in places forming a prominent hogback. The Ladron Mountains are drained by a roughly radial pattern of intermittent streams which have cut deep steep-walled canyons. The climate of the area is arid to semiarid, with an average annual precipitation of less than 10 in $(25.4 \mathrm{~cm})$.

\section{METHODS OF STUDY}

\section{Sample Medium}

Analyses of stream sediment material ideally represent the chemical composition of rock material eroded from the drainage basin upstream from the 


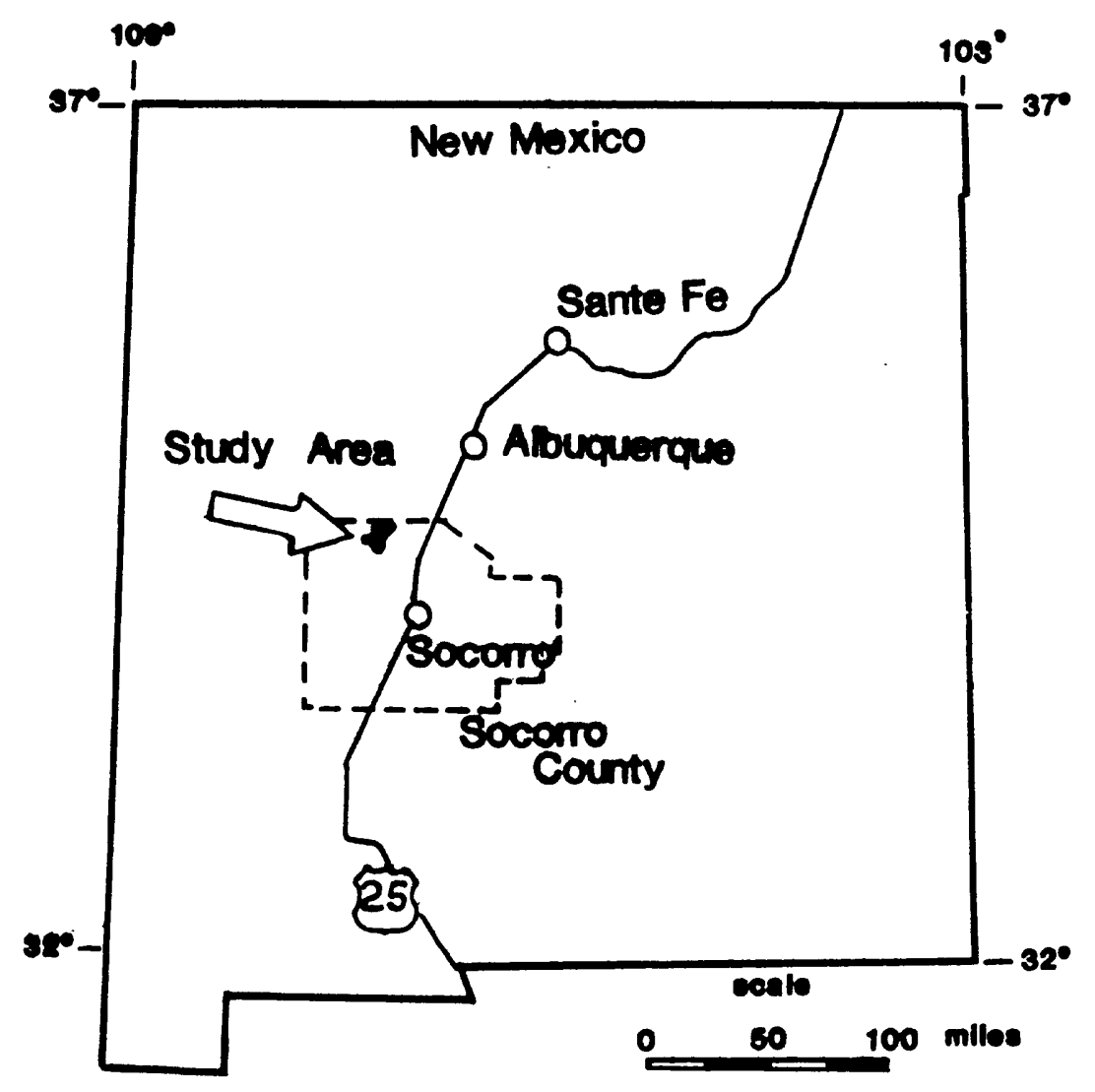

Figure 1. Location map of the Sierra Ladrones Wilderness Study Area, Socorro County, New Mexico. 
sample site. Such information is useful in identifying basins which contain concentrations of elements that may be derived from mineral deposits. The heavy-mineral fraction of stream-sediment material is particularly suited for identifying anomalous concentrations of elements occurring in heavy, resistant minerals which are commonly concentrated in mineral deposits. In addition, the selective gravity separation of certain minerals permits determination of elements which are not easily detected in bulk stream sediment.

\section{Sample Collection}

Fifty-one sites were sampled in this reconnaissance study (fig. 2). The sites selected for sampling are along the mountain range front, high enough in the mountains such that sediment collected was representative of the active drainage. The drainage basins sampled ranged from 1 to $3 \mathrm{sq} \mathrm{mi}$. Sample density was approximately one site every $1.5 \mathrm{sq} \mathrm{mi}$.

\section{Sample Preparation}

The sample medium for this study was the nonmagnetic fraction of panned concentrates from drainage sediment. The heavy-mineral-concentrate samples were collected from active sediment in drainage channe1s. Each sample was a composite from several localities within an area that may extend as much as 30 feet from the site plotted on the map. Each sample was sieved through a 2-mm (10-mesh) screen to remove coarse materia1. The minus-2-mm material was panned to remove most of the quartz, feldspar, organic materia1, and claysized material.

After the panned concentrates were air dried, they were put through a bromoform (specific gravity 2.8) separation to remove remaining quartz and feldspar. The heavy fraction was then separated into three fractions using a modified Frantz Isodynamic Magnetic Separator. The three fractions produced include: the $\mathrm{Cl}$ - dominated by magnet ite and 1imonite; the C2 - dominated by heavy rock-forming minerals, such as garnet and hornblende; and the C3 dominated by heavy accessory minerals, such as zircon and apatite, and the majority of ore-related minerals. Only the $\mathrm{C} 3$ fraction was analyzed for this study. Due to insufficient quantities of sample collected, a split of the C3 fraction was not available for mineralogical analysis.

\section{Sample Analysis}

The C3 fraction was analyzed for 31 elements using a semiquantitative, direct-current arc emission-spectrographic method (Grimes and Marranzino, 1968). The elements analyzed and their lower detection limits are 1isted in table 1. Spectrographic results were obtained by visual comparison of sample spectra against standard-derived spectra, and are reported geometrically over any given order of magnitude in the series 10, 15, 20,30, 50, 70, 100, etc. The precision of the method is approximately plus or minus one reporting interval at the 83 percent confidence level and plus or minus two intervals at the 96 percent confidence leve 1 (Motooka and Grimes, 1976). Values determined for the elements $\mathrm{Fe}, \mathrm{Mg}, \mathrm{Ca}$, and $\mathrm{Ti}$ are reported in weight percent, while all others are reported in parts per million (micrograms/gram). Analytical data for samples from the Sierra Ladrones WSA are presented in table 2. 


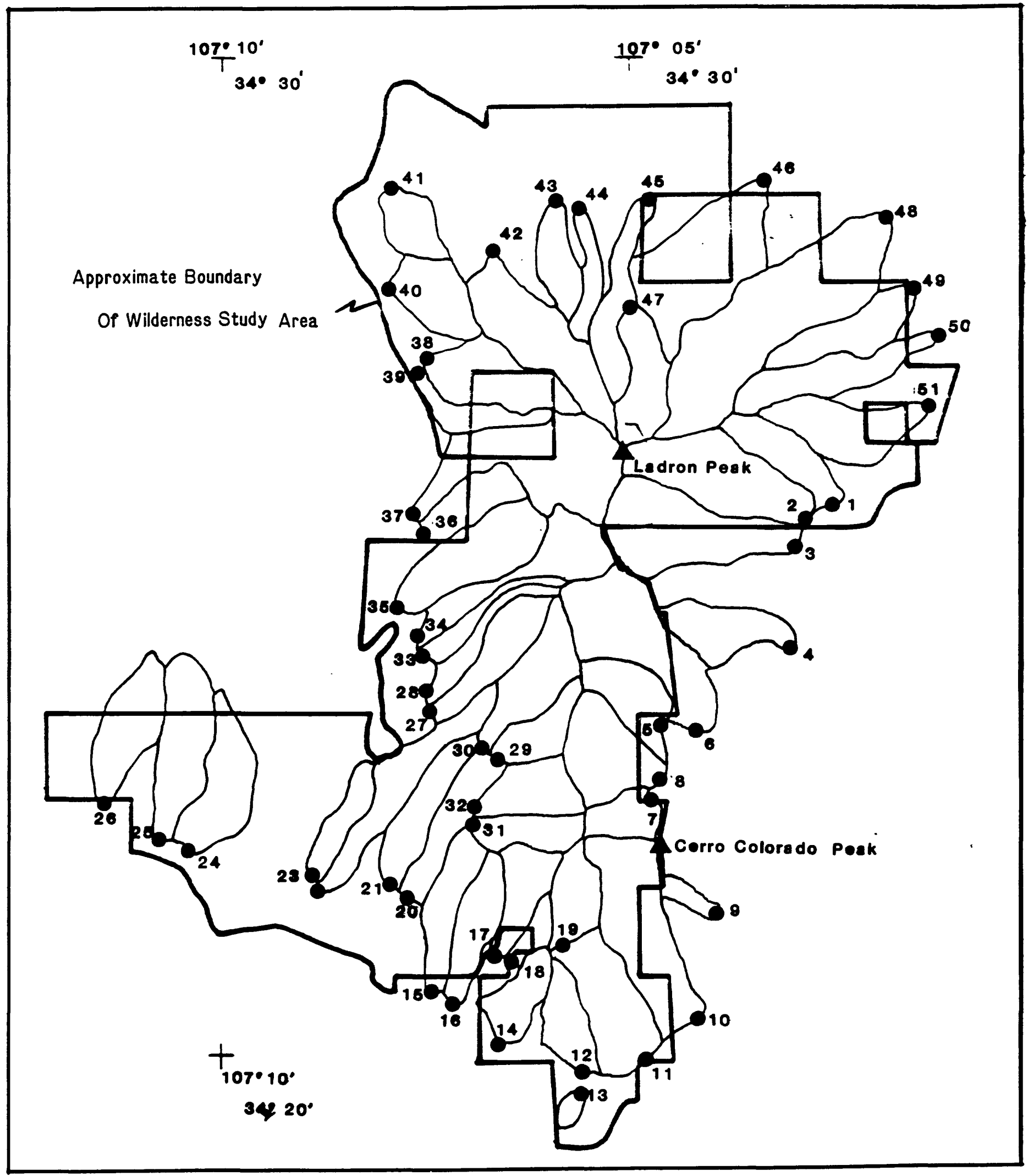

Figure 2. Sample location map of the Sierra Ladrones Wilderness Study Area (NM-020-016), Socorro County, New Mexico. 


\section{ROCK ANALYSIS STORAGE SYSTEM}

Upon completion of the analytical work, the analytical results were entered into a computer-based file as part of the USGS Rock Analys is Storage System (RASS) data base. This data base contains both descriptive geological information and analytical data. Any of this information may be retrieved and converted to a binary form (STATPAC) for computerized analys is or publication (VanTrump and Miesch, 1976).

\section{DESCRIPTION OF DATA TABLES}

Table 2 contains the analytical results for the C3 fraction of heavymineral concentrates. The data are arranged such that the first column contains the USGS-assigned sample numbers. These numbers correspond to those shown in figure 2, except the prefix "SL" and the suffix "H" have been eliminated from figure 2. The designation " $s$ " on element heading indicates spectrographic analysis. The letter " $N$ " in the table indicates that an element was looked for but not observed. If an element was observed but was be low the lowest reporting value, a "less than" symbol $(<)$ was entered in the table in front of the lower limit of determination. If an element was observed but was above the upper reporting value, a "greater than" symbol (>) was entered in the table in front of the upper limit of determination. Because of the formatting used in the computer program that produced table 2 , some of the elements 1 isted in this table ( $\mathrm{Fe}, \mathrm{Mg}, \mathrm{Ca}$, and $\mathrm{Ti}$ ) carry one or more nonsignificant digits to the right of the significant digits. The analyst did not determine these elements to the accuracy suggested by the extra zeros.

The spectrographic determinations for $\mathrm{Au}, \mathrm{As}, \mathrm{Cd}$, and $\mathrm{Sb}$ were $\mathrm{a} 11$ not observed below the lower limits of determination shown in table 1 , and therefore are not included in table 2.

\section{REFERENCES CITED}

Black, B.A., 1964, The geology of the northern and eastern parts of the Ladron Mountains, Socorro County, New Mexico: M.S. Thesis, University of New Mexico, $117 \mathrm{p}$.

Condie, K.C., 1976, Precambrian rocks of Ladron Mountains, Socorro County, New Mexico: New Mexico Bureau of Mines and Mineral Resources Geologic Map 38.

Grimes, D.J., and Marranzino, A.P., 1968, Direct-current arc and alternating current spark emission spectrographic field methods for the semiquantitative analys is of geologic materials: U.S. Geological Survey Circular 591, $6 \mathrm{p}$.

Haederle, W.F., 1966, Structure and metamorphism in the southern Sierra Ladron, Socorro County, New Mexico: M.S. Thesis, New Mexico Institute Mining Technology, $56 \mathrm{p}$.

Motooka, J.M., and Grimes, D.J., 1976, Analytical precision of one-sixth order semiquantitative spectrographic analysis: U.S. Geological Survey Circular 738, $25 \mathrm{p}$.

Noble, E.A., 1950, Geology of the southern Ladron Mountains, Socorro County, New Mexico: M.S. Thesis, University of New Mexico, 81 p.

VanTrump, George, Jr., and Miesch, A. T., 1977, The U.S. Geological Survey RASS-STATPAC system for management and statistical reduction of geochemical data: Computers and Geosciences, v. 3, p. 475-488. 
TABLE 1.--Limits of determination for the spectrographic analysis of heavy-mineral concentrates

[The values shown are the lower limits of determination assigned by the Grimes and Marranzino method, except for those values in parentheses, which are the lower values assigned by the Myers and others method. The spectrographic limits of determination for heavy-mineral-concentrate samples are based on a 5-mg sample, and are therefore two reporting intervals higher than the limits which are given for rocks.l

Elements Lower determination limit Upper determination limit

Percent

\begin{tabular}{lcc}
\hline Iron (Fe) & 0.05 & 20 \\
Magnesium (Mg) & .02 & 10 \\
Calcium (Ca) & .05 & 20 \\
Titanium ( $\mathrm{Ti})$ & .002 & 1 \\
\hline
\end{tabular}

Parts per million

\begin{tabular}{|c|c|c|c|}
\hline $\begin{array}{l}\text { Manganese (Mn) } \\
\text { Silver (Ag) } \\
\text { Arsenic (As) } \\
\text { Gold (Au) } \\
\text { Boron (B) } \\
\text { Barium (Ba) } \\
\text { Beryllium (Be) } \\
\text { Bismuth (Bi) } \\
\text { Cadmium (Cd) } \\
\text { Cobalt (Co) } \\
\text { Chromium (Cr) } \\
\text { Copper (Cu) } \\
\text { Lanthanum (La) } \\
\text { Molybdenum (Mo) } \\
\text { Niobium (Nb) } \\
\text { Nickel (Ni) } \\
\text { Lead (Pb) } \\
\text { Antimony (Sb) } \\
\text { Scandium (SC) } \\
\text { Tin (Sn) } \\
\text { Strontium (Sr) } \\
\text { Vanadium (V) } \\
\text { Tungsten (W) } \\
\text { Yttrium (Y) } \\
\text { Zinc (Zn) } \\
\text { Zirconium (Zr) } \\
\text { Thorium (Th) }\end{array}$ & $\begin{array}{c}10 \\
0.5 \\
200 \\
10 \\
10 \\
20 \\
1 \\
10 \\
20 \\
5 \\
10 \\
5 \\
20 \\
5 \\
20 \\
5 \\
10 \\
100 \\
5 \\
10 \\
100 \\
10 \\
50 \\
10 \\
200 \\
10 \\
100\end{array}$ & $\begin{array}{r}(700) \\
(15)\end{array}$ & $\begin{array}{r}5,000 \\
5,000 \\
10,000 \\
500 \\
2,000 \\
5,000 \\
1,000 \\
1,000 \\
500 \\
2,000 \\
5,000 \\
20,000 \\
1,000 \\
2,000 \\
2,000 \\
5,000 \\
20,000 \\
10,000 \\
100 \\
1,000 \\
5,000 \\
10,000 \\
10,000 \\
2,000 \\
10,000 \\
1,000 \\
2,000\end{array}$ \\
\hline
\end{tabular}




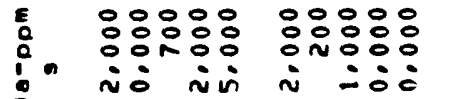

i 음

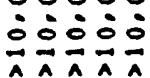

$\therefore: \therefore::$

$\because \because 0: 0$

ónio:

$\therefore:: ㅇ$

$\because: 0: 0$

$\therefore 0000$
융유:

ㅁํㅇㅇㅇㅇ
::요융

in $=$ i

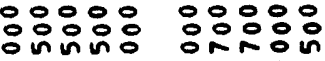

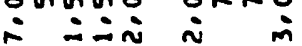

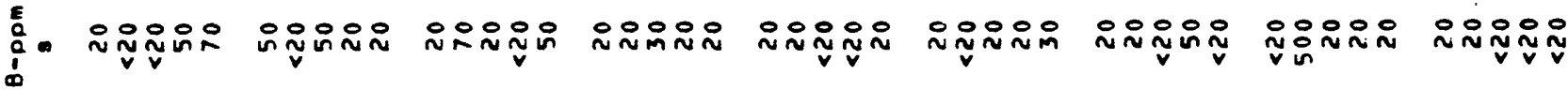

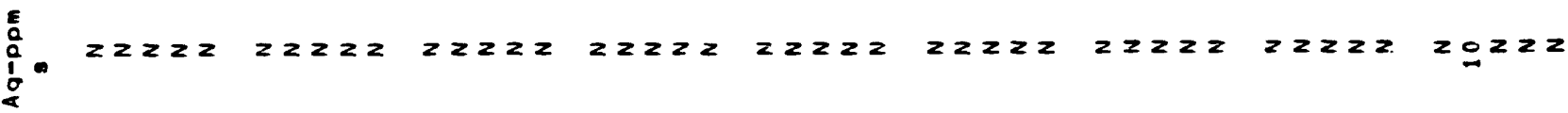

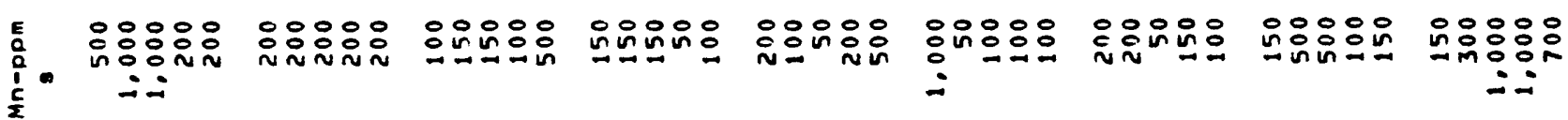

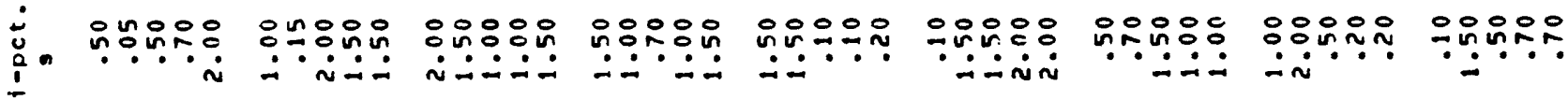

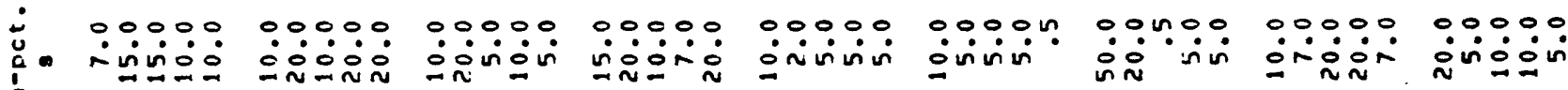
i

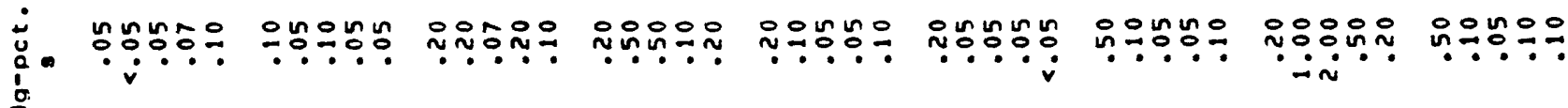
葛

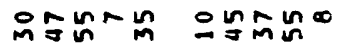

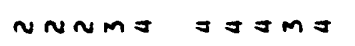

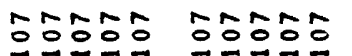

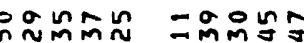

zungor roour

hatâ

ํํํำำ

=rroo

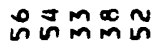

Domar

응ํㅇ응

응ํํ응

m䋑 กMmก⿻上

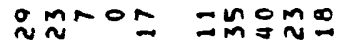

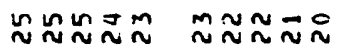

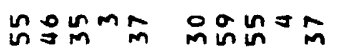

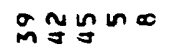

음유

ㅇㅠㅠㅠ

$\bar{\sim} \approx \approx \sim ⿻$

NNNNN

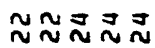

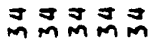

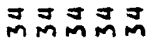

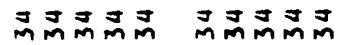

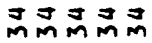

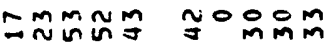

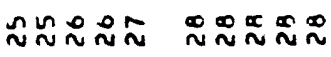

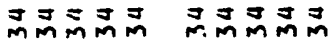

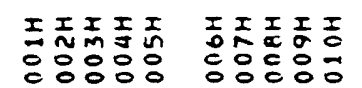

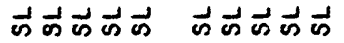

三杰忈甹志

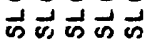

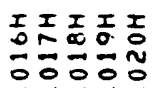
काजिएक
I杰志甹志 กักั์ธี काषेक
I도도옹

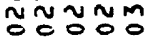

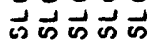
I资忈甹忈

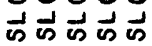

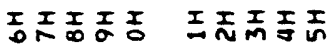

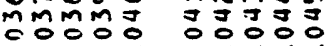

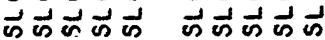




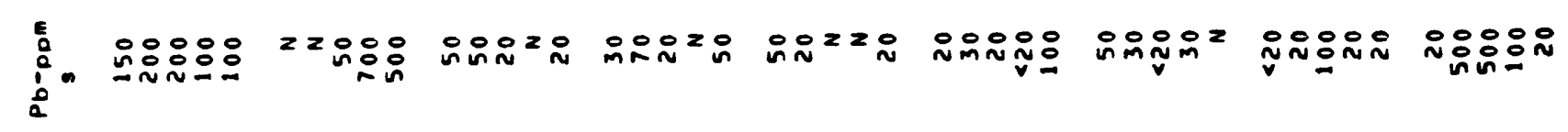

䶭

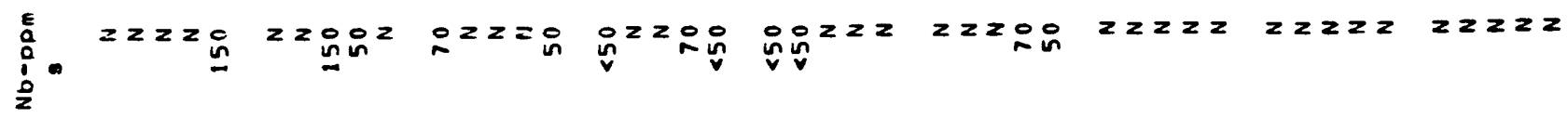

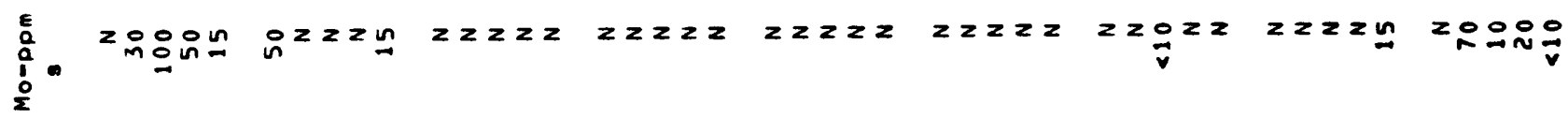
岸导

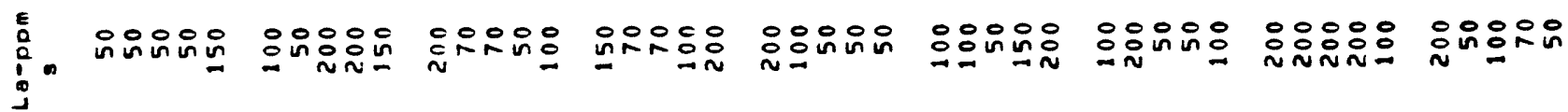

厙

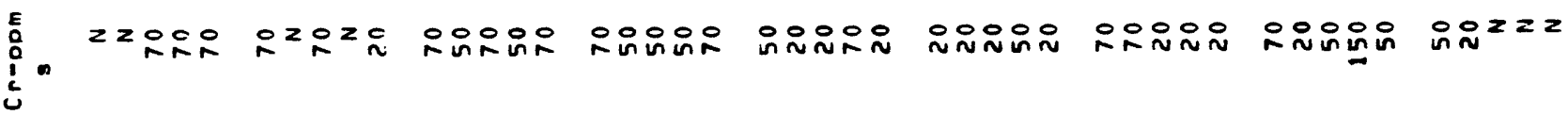

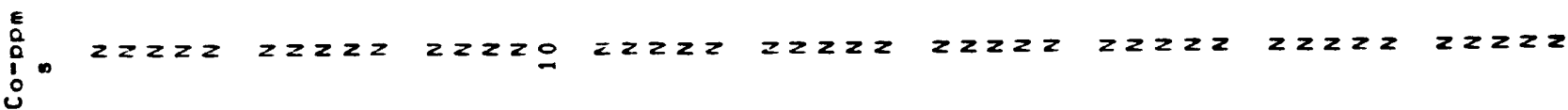

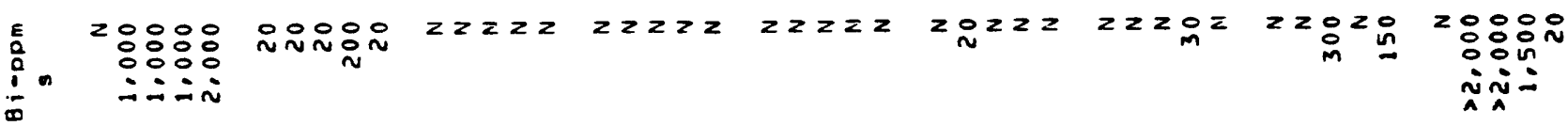

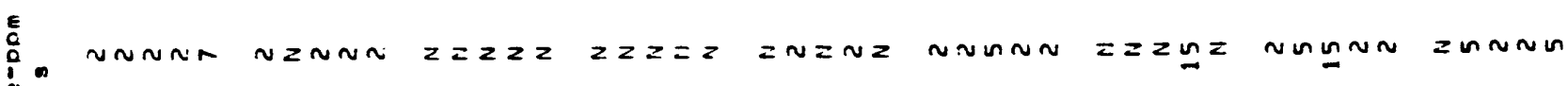

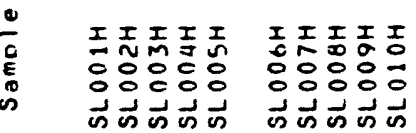

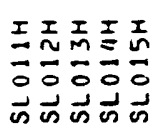

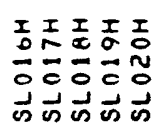

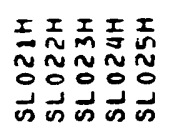

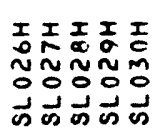

I王志至志

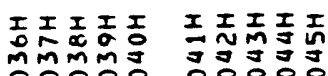

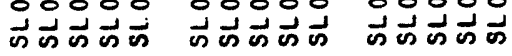




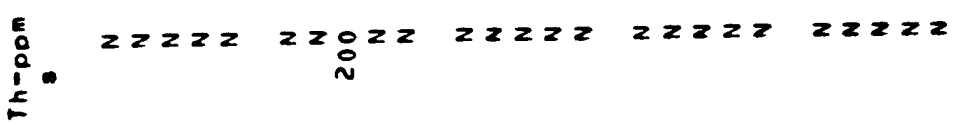

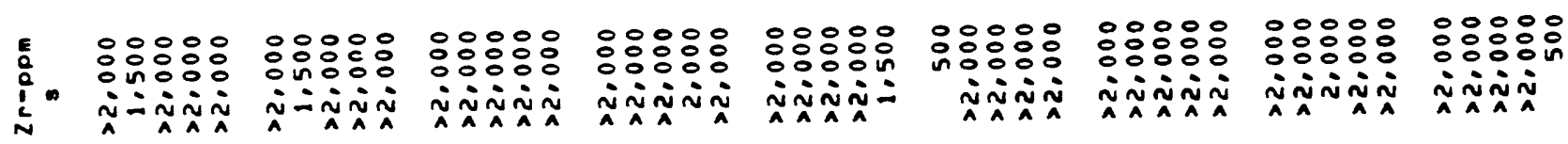

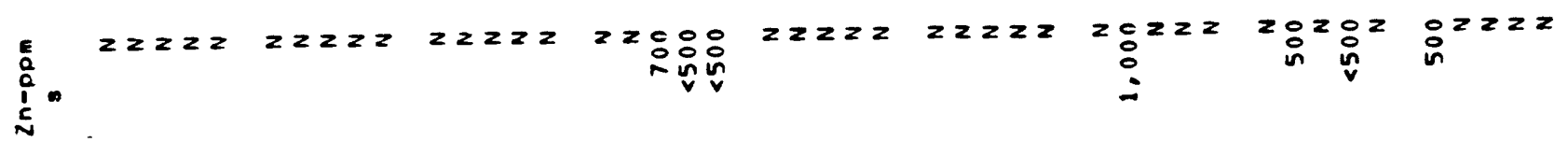

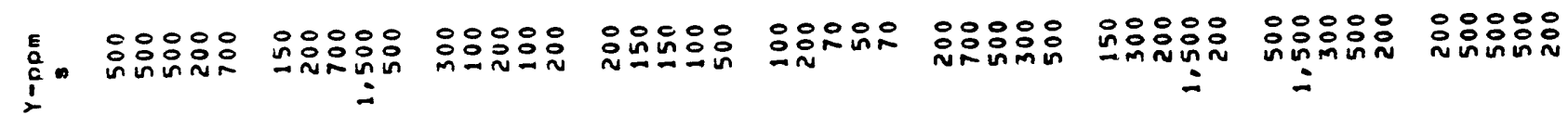

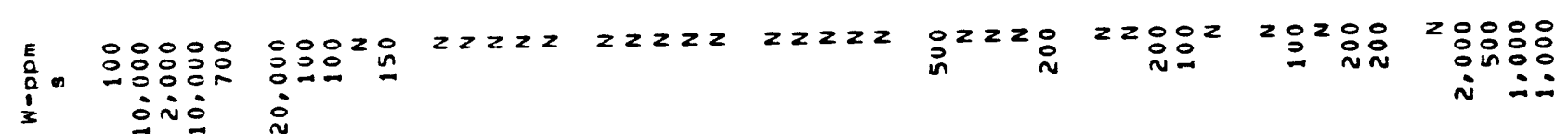

\section{$\sum_{\frac{a}{2}}^{a}$}

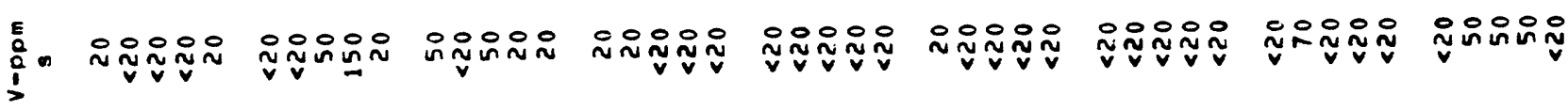

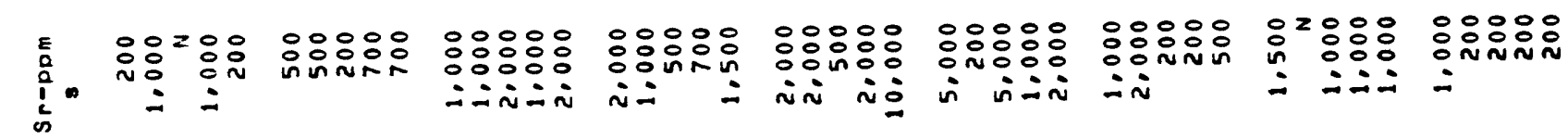

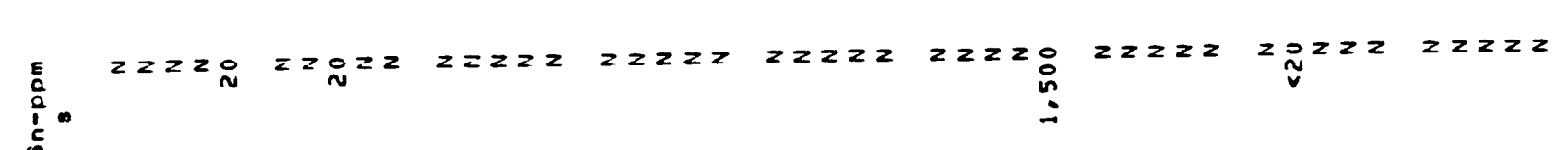

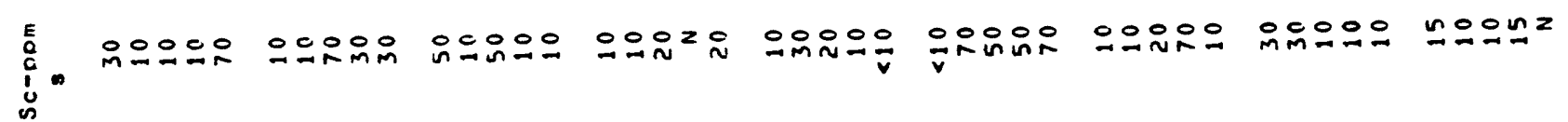

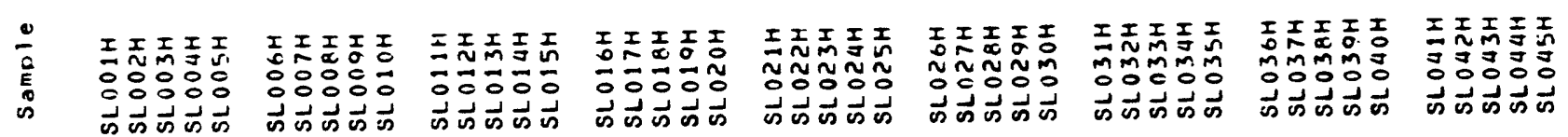


:

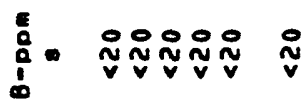

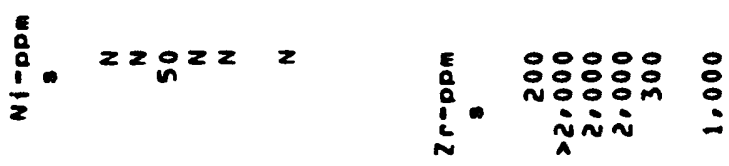

: $22222=$

$E$
$\vdots$
$\vdots$

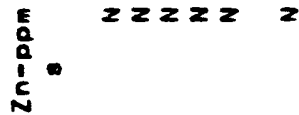

음 용융유 운

$\vdots_{0}^{6} \quad 20<22=$

E 응용요 은

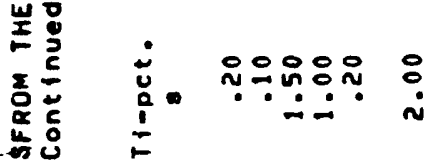

을 응요용

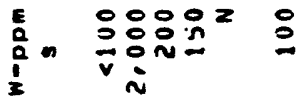

ú

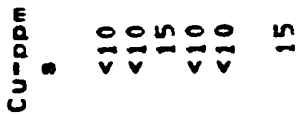

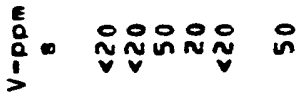

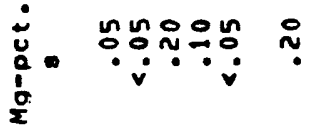

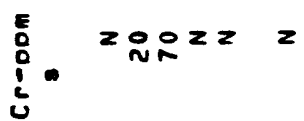

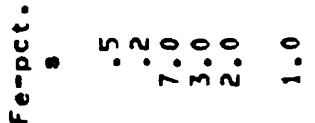

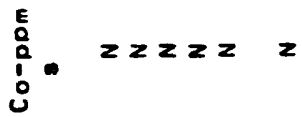

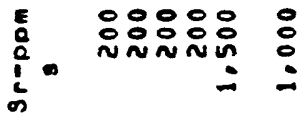

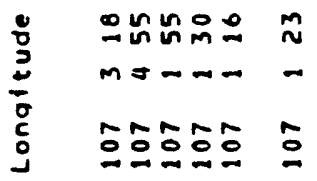

$\begin{array}{cc}\text { E } & 20^{2} \ln ^{2} \\ \frac{0}{a} n & \vdots\end{array}$

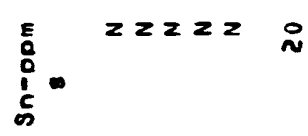

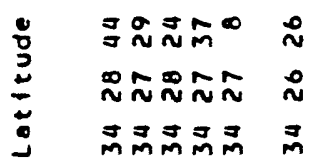

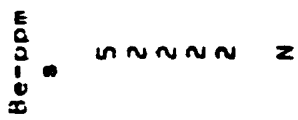

造 $\quad z<0020$

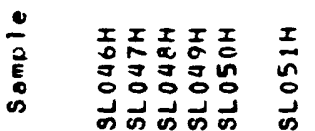

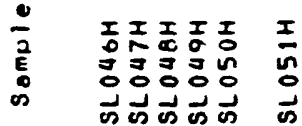

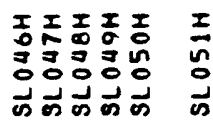

